Article

\title{
Characteristic Evaluation on the Cooling Performance of an Electrical Air Conditioning System Using R744 for a Fuel Cell Electric Vehicle
}

\author{
Moo-Yeon Lee *, Ho-Seong Lee and Hong-Phil Won
}

Korea Automotive Technology Institute, 74 Yongjung-Ri, Pungse-Myun, Dongnam-Gu, Chonan-Si, 330-012, Korea; E-Mails: leehs@katech.re.kr (H.-S.L.); jpwon@katech.re.kr (H.-P.W.)

* Author to whom correspondence should be addressed; E-Mail: mylee@katech.re.kr; Tel.: +82-41-559-3312; Fax: +82-41-559-3091.

Received: 6 February 2012; in revised form: 4 April 2012 / Accepted: 8 May 2012 /

Published: 11 May 2012

\begin{abstract}
The objective of this study was to investigate the cooling performance characteristics of an electrical air conditioning system using R744 as an alternative of $\mathrm{R}-134 \mathrm{a}$ for a fuel cell electric vehicle. In order to analyze the cooling performance characteristics of the air conditioning system using R744 for a fuel cell electric vehicle, an electrical air conditioning system using R744 was developed and tested under various operating conditions according to both inlet air conditions of the gas cooler and evaporator and compressor speed. The cooling capacity and coefficient of performance (COP) for cooling of the tested air conditioning system were up to $6.4 \mathrm{~kW}$ and 2.5 , respectively. In addition, the electrical air conditioning system with R744 using an inverter driven compressor showed better performance than the conventional air conditioning system with R-134a under the same operating conditions. The observed cooling performance of the developed electrical air conditioning system was found to be sufficient for cooling loads under various real driving conditions for a fuel cell electric vehicle.
\end{abstract}

Keywords: air conditioning; electrical compressor; COP; R744; fuel cell electric vehicle

\section{Nomenclature}

COP Coefficient of performance

FEM Front end module

$h \quad$ Enthalpy $(\mathrm{kJ} / \mathrm{kg})$ 


$\begin{array}{ll}\dot{m} & \text { Mass flow rate }(\mathrm{kg} / \mathrm{h}) \\ \dot{Q} & \text { Heat transfer rate }(\mathrm{W}) \\ R P M & \text { Revolution per minute }(\mathrm{rev} / \mathrm{min}) \\ R h & \text { Relative humidity }(\%) \\ T & \text { Temperature }\left({ }^{\circ} \mathrm{C}\right) \\ V & \text { Velocity }(\mathrm{m} / \mathrm{s}) \\ \text { Subscripts } \\ \text { A } & \text { air } \\ \text { comp } & \text { compressor } \\ \text { in } & \text { inlet } \\ \text { out } & \text { outlet } \\ p & \text { pressure } \\ \text { ref } & \text { refrigerant }\end{array}$

\section{Introduction}

As measures against to the increase of environmental pollution and ozone layer depletion, both the Kyoto and Montreal protocols, have banned or limit the use of chemical refrigerants and fossil fuel energies. However, modern refrigerant systems must provide better cooling and heating performance in the form of reliability, small size, low weight, etc. Therefore, various industries and especially the automobile industry have found value in studying and using natural refrigerants. The above-mentioned requirements can be met by using R744 in automobile air conditioning systems. R744 has been considered as an alternative to CFC and HCFC in air conditioning and refrigeration system because it has negligible the ozone depletion potential (ODP) and global warming potential (GWP), as well as many additional merits such as lack of toxicity, no flammability, high volumetric capacity and better heat transfer properties [1,2]. So, the R744 was considered as a vehicle refrigerant in this study.

Worldwide, in light of limited natural resources, the automotive industry is trying to reduce fossil fuel consumption, so they are developing zero emission vehicles such as the electric vehicle, fuel cell electric vehicle, hybrid electric vehicle, etc. However electric vehicles and hybrid vehicles that use battery packs have an important limitation: a short driving range when either the heating or the cooling system is operating under cold or hot weather conditions, respectively. Therefore, among the several types of zero emission vehicles, the fuel cell electric vehicle (FCEV) is considered as a possible option for realization of longer driving ranges, as an alternative to internal combustion engines [3,4].

Many studies have investigated, experimentally and numerically, the cooling performances of the R744 air conditioning system for vehicles using internal combustion engines under warm weather conditions. Brown et al. reported a comparative analysis of automotive air conditioning systems operating with R744 and R134a [5]. Park et al. studied the steady state and dynamic characteristics of a carbon dioxide air-conditioning system for vehicles [6]. Tamura et al. reported an experimental study on an automotive cooling and heating air conditioning system using $\mathrm{CO}_{2}$ as a refrigerant [7]. Kim et al.

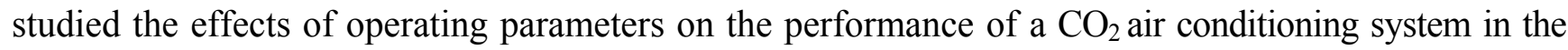


internal combustion engine. They proposed a diagram used in an optimum high pressure control algorithm for the transcritical $\mathrm{CO}_{2}$ cycle to achieve the maximum COP [8]. However, there is a limited amount of data available on cooling systems for the cabins of fuel cell electric vehicles (FCEVs). Therefore, to combat the two major issues mentioned above, this study evaluates and investigates the cooling performance characteristics of the electrical air conditioning system using R744 as an alternative to R-134a for a fuel cell electric vehicle, although Kim et al. previously studied the performance of a stack cooling system using $\mathrm{CO}_{2}$ in fuel cell vehicles [9]. A modified electrical air conditioning system using R744 was developed. Experiments to analyze the cooling performance characteristics of this modified air conditioning system were carried out for various operating conditions of inlet air temperature, air flow rate in the gas cooler side and in the evaporator side, and compressor speed.

\section{Experimental Setup and Data}

\subsection{Test Setup}

Figure 1 shows the schematic diagram of the basic test setup to measure the performance of the electrical air conditioning system for the fuel cell electric vehicle using R744.

Figure 1. Schematic diagram of the test setup.

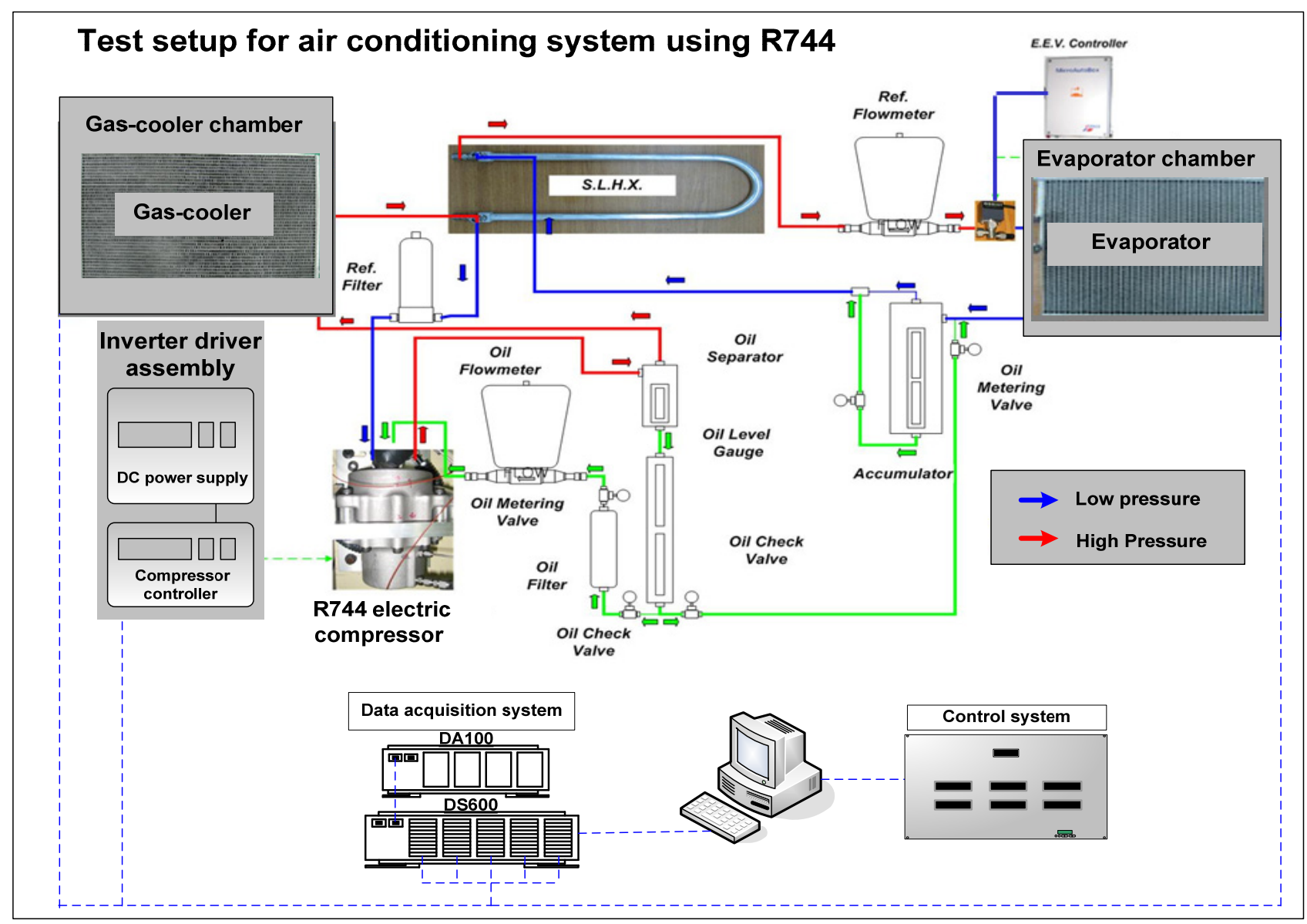

The test setup mainly consisted of an electric driven compressor for $\mathrm{CO}_{2}$, two heat exchangers (gas cooler and evaporator), an expansion device (electronic control type), and accumulator. The test setups 
for the gas cooler and evaporator side were installed in a psychrometric calorimeter, which provided pre-controlled ambient temperature. The psychrometric calorimeter, equipped with an air-handling unit including a cooling coil, a heating coil, and a humidifier, was set to $27{ }^{\circ} \mathrm{C} \sim 42{ }^{\circ} \mathrm{C}$ to an accuracy of $\pm 0.2{ }^{\circ} \mathrm{C}$. The psychrometric calorimeter was controlled by using the PID control method. Both an evaporator and a gas cooler with multi-flow type were installed in the psychrometric calorimeters for the purpose of controlling the air-side inlet conditions.

The electric compressor for R744 was variable speed type and the current used to drive the compressor was measured by the inverter driver (SV-IG5A) manufactured by LS industrial Systems. Compressor work was calculated based on the power input and current. The power input was measured exactly to evaluate the electrical air conditioning system. During the experiments, the major operating parameters were monitored graphically and numerically in real time. In order to calculate and evaluate the performance of the electrical air conditioning system the temperature, pressure, and the mass flow rate were measured. Table 1 shows the specifications of the electrical air conditioning system using R744 for a fuel cell electric vehicle. Table 2 shows the test conditions used in this study. During the experiments, the indoor air temperature was set to $27,35,42{ }^{\circ} \mathrm{C}$ with relative humidity of $50 \%$ and the air flow rate was set to $4.0-7.0 \mathrm{~m}^{3} / \mathrm{min}$.

Table 1. Components specifications of electrical air conditioning system using R744.

\begin{tabular}{|c|c|c|}
\hline Components & & Specifications \\
\hline $\begin{array}{c}\text { Stack capacity of the fuel cell } \\
\text { electric vehicle }\end{array}$ & Capacity (kW) & 80.0 \\
\hline Evaporator & Capacity (kW) & 5.0 at $4 \mathrm{~m}^{3} / \mathrm{min}$ and $6000 \mathrm{rpm}$ \\
\hline (Interior heat exchanger) & Type, core size $\left(\mathrm{mm}^{3}\right)$ & Multi-flow type, W $250 \times$ H $260 \times$ D 35 \\
\hline Gas cooler & capacity $(\mathrm{kW})$ & 7.5 at $4 \mathrm{~m} / \mathrm{s}, 35^{\circ} \mathrm{C}$ and $6000 \mathrm{rpm}$ \\
\hline (Exterior heat exchanger) & Type, core size $\left(\mathrm{mm}^{3}\right)$ & Multi-flow type, W $630 \times$ H $375 \times$ D 16 \\
\hline Internal heat exchanger & Capacity (kW) & $0.5 \sim 1.5$ at $2 \mathrm{~m} / \mathrm{s}$ and $6000 \mathrm{rpm}$ \\
\hline \multirow{3}{*}{ Compressor } & Type, length (mm) & Co-axial, $750 \sim 1250$ \\
\hline & Type & Electric driven compressor \\
\hline & Displacement (cc/rev) & 7.5 \\
\hline \multirow[t]{2}{*}{ Expansion valve } & Type & Electronic control (PWM) \\
\hline & Flow rate $(\mathrm{kg} / \mathrm{h})$ & $50 \sim 250$ \\
\hline \multirow[t]{2}{*}{ Accumulator } & Pressure (bar) & Max. 125 at $90^{\circ} \mathrm{C}$ \\
\hline & Volume (cc) & 550 \\
\hline
\end{tabular}

Table 2. Test Conditions.

\begin{tabular}{cc}
\hline Components & Conditions \\
\hline Compressor speed (RPM) & $3000,4000,5000,6000$ \\
$\mathrm{~V}_{\text {gas cooler, in }}(\mathrm{m} / \mathrm{s})$ & $2.0,4.0$ \\
$\mathrm{~T}_{\text {gas cooler, in }}\left({ }^{\circ} \mathrm{C}\right)$ & $27.0,35.0,42.0$ \\
$\operatorname{Rh}_{\text {evaporator }}(\%)$ & 50.0 \\
$\mathrm{~T}_{\text {evaporator, in }}\left({ }^{\circ} \mathrm{C}\right)$ & $27.0,35.0,42.0$ \\
$\mathrm{Q}_{\text {evaporator, in }}\left(\mathrm{m}^{3} / \mathrm{min}\right)$ & $4.0,7.0$ \\
\hline
\end{tabular}


Outdoor air temperatures and air flow rates on the evaporator side to simulate the FEM (front end module) of the passenger vehicle were varied from $27{ }^{\circ} \mathrm{C}$ to $42{ }^{\circ} \mathrm{C}$ and $2.0 \mathrm{~m} / \mathrm{s}$ to $4.0 \mathrm{~m} / \mathrm{s}$, respectively. The compressor speed was set variously at $3000 \mathrm{rev} / \mathrm{min}, 4000 \mathrm{rev} / \mathrm{min}, 5000 \mathrm{rev} / \mathrm{min}$ and $6000 \mathrm{rev} / \mathrm{min}$. The displacement of the compressor was $7.5 \mathrm{cc} / \mathrm{rev}$.

Figure 2 shows a schematic diagram of the air velocity through FEM and test results of the air flow rate with the input voltage of the fan. In this study, the air velocities through the FEM at idle condition and $100 \mathrm{~km} / \mathrm{h}$ driving condition were on average $2.3 \mathrm{~m} / \mathrm{s}$ and $6.0 \mathrm{~m} / \mathrm{s}$, respectively. Idle and $100 \mathrm{~km} / \mathrm{h}$ conditions were chosen for reflecting the air velocities through FEM (consisted of the condenser and the radiator for an engine) of the internal combustion engine. These were used as the inlet air conditions of the gas cooler during the tests.

Figure 2. Test results of the air flow rate of the HVAC system. (a) Schematic diagram of FEM and HVAC module; (b) Air flow rate with input voltage of the fan.

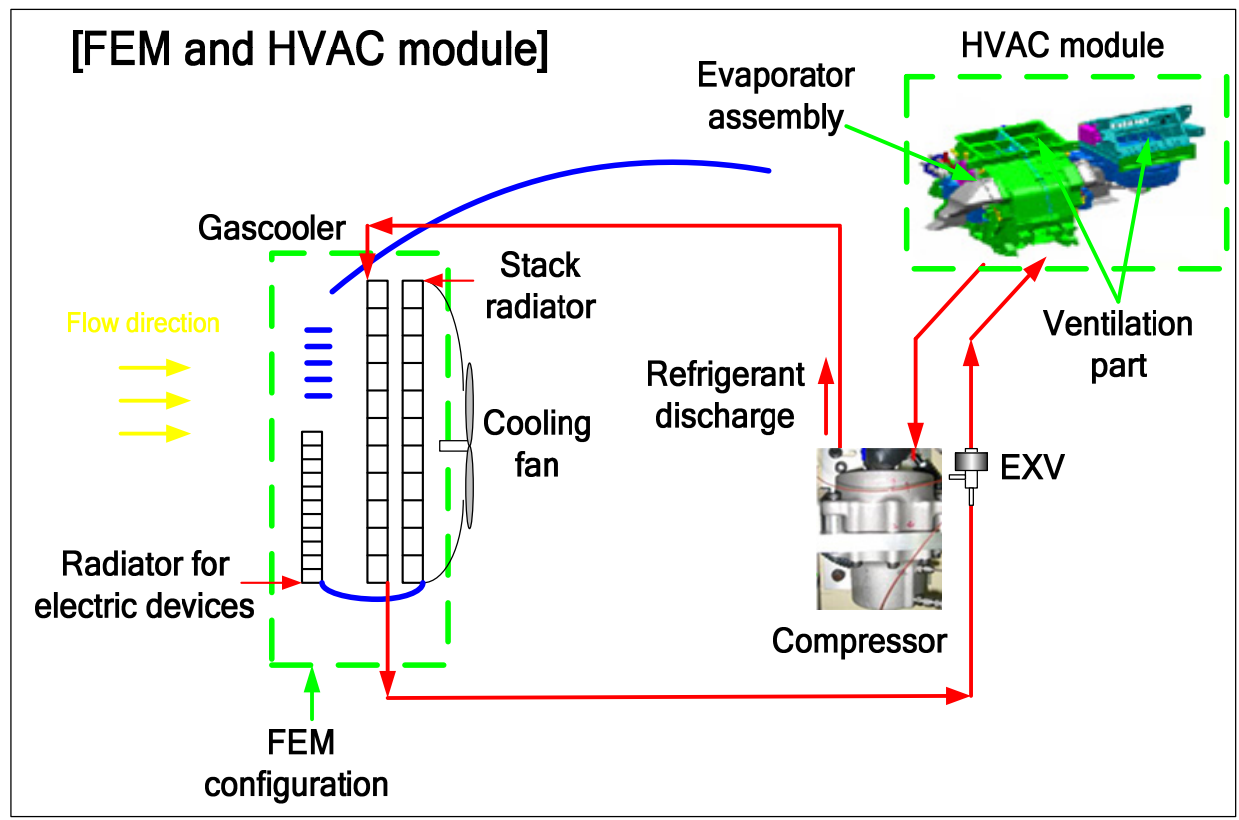

(a)

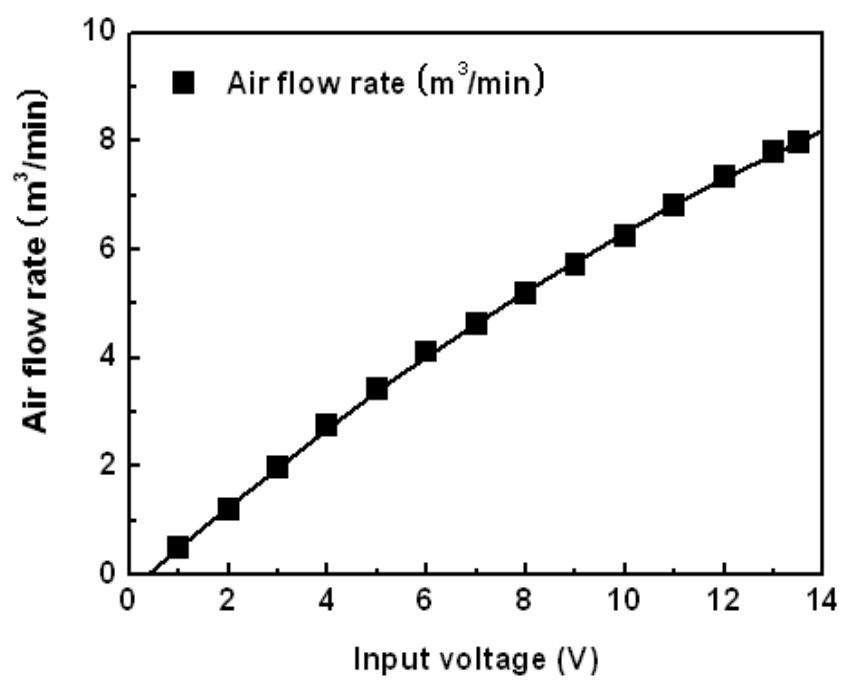

(b) 
FEM for the fuel cell electric vehicle is combination of the gas cooler, the radiators for stack and electric devices such as the driving motor and inverter, and the cooling fan at the front of the passenger vehicle as shown in Figure 2a. All heat exchangers were closely installed in the FEM due to the limited space in the vehicle. The air flow rates at the HVAC module were obtained according to the input voltages of the blower; they were $4.0 \mathrm{~m}^{3} / \mathrm{min}$ at the input voltage of $6.0 \mathrm{~V}$ and $7.0 \mathrm{~m}^{3} / \mathrm{min}$ at the input voltage of $12.0 \mathrm{~V}$, as shown in Figure $2 \mathrm{~b}$. The above tests were performed to obtain the real air flow rates of the HVAC module for the real fuel cell electric vehicle. The HVAC module consisted of the evaporator assembly and air ventilation parts.

Table 3. Test equipment and uncertainty of the experimental parameters.

\begin{tabular}{cc}
\hline Items & Accuracy \\
\hline Thermocouples (T-type) & $\pm 0.1{ }^{\circ} \mathrm{C}$ \\
Pressure gage (Sensors, PI3H) & $\pm 0.1 \%(\mathrm{Max} .250 \mathrm{bar})$ \\
Mass flow meter (Coriolis type) & $\pm 0.15 \%, \mathrm{Max} .680 \mathrm{~kg} / \mathrm{h}$ \\
Data logger (Gantner) & E. Gate IP (V3) $(2.93 \mathrm{~W} @ 12.06 \mathrm{~V})$ \\
Cooling capacity & $4.5 \%$ \\
Cooling COP & $5.8 \%$ \\
\hline
\end{tabular}

Table 3 shows the uncertainties of the parameter measurements. Refrigerant and air temperatures were measured with thermocouples. The thermocouples were calibrated to an accuracy of $\pm 0.1{ }^{\circ} \mathrm{C}$. The refrigerant flow rate was measured by a Coriolis type flow meter with an uncertainty of $\pm 0.15 \%$ and an upper limit of $680 \mathrm{~kg} / \mathrm{h}$. This flow meter was installed between the outlet tube of the internal heat exchanger and the inlet of the expansion valve to minimize the measurement errors. Pressure sensors, which can measure absolute pressure up to 250 bar with an uncertainty of $\pm 0.1 \%$, were installed at the inlet and outlet of each component. In order to verify the measured data of the cooling capacity and the cooling COP, an uncertainty analysis was performed in accordance with the $95 \%$ confidence level set by the standards of ANSI/ASME (1985) and Moffat [10,11]. The precision limits and bias limits of all the parameters associated with heating capacity and heating COP were estimated. The average uncertainties of the experimental data on cooling capacity and cooling COP were $4.5 \%$ and $5.8 \%$, respectively.

\subsection{Data Reduction}

Figure 3 shows the heat balance between the air side and the refrigerant side used in this study. The heat transfer rate of the refrigerant side was calculated by the refrigerant enthalpy method (ANSI/AMCA 210, 1985 and ASHRAE Standard 116, 1983) [12]. Equation (1) was used to calculate the refrigerant side heat transfer rate. The heat transfer rate of the air side was determined by utilizing both the air flow rate and enthalpy difference, which were calculated by Equation (2), which was used to calculate the air side heat transfer rate:

$$
\begin{gathered}
\dot{Q}_{r e f}=\dot{m}_{r e f} \Delta h_{r e f} \\
\dot{Q}_{a}=\dot{m}_{a} C_{p, a}\left(T_{a, \text { in }}-T_{a, \text { out }}\right)
\end{gathered}
$$


Figure 3. Heat balance between the air side and the refrigerant side.

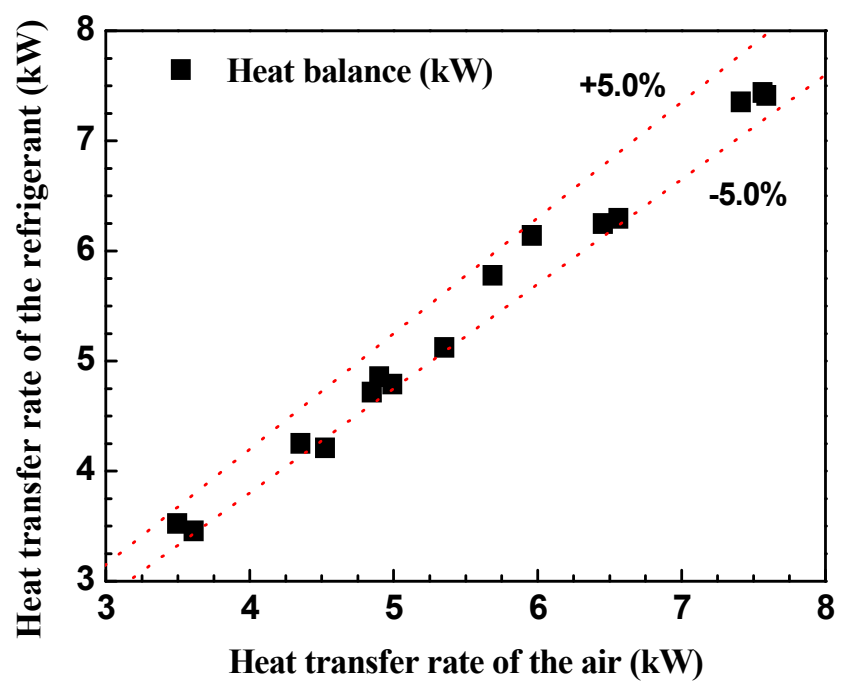

The heat transfer rate of the air side was consistent with the heat transfer rate of the refrigerant side within $\pm 5 \%$, so the present experimental setup was found to be appropriate. The cooling COP (coefficient of performance) of the electrical air conditioning system was calculated by Equation (3).

$$
C O P=\frac{\dot{Q}_{a}}{\dot{W}_{c o m p}}
$$

\section{Results and Discussion}

Cooling performance characteristics of the electrical air conditioning system using R744 were investigated and evaluated. The cooling capacity and the cooling COP needed to satisfy the cooling load in the tested vehicle's cabin room under hot weather conditions were obtained. Generally, the maximum cooling load for a medium size passenger vehicle under the hottest weather conditions (over $35.0^{\circ} \mathrm{C}$ of an outside temperature) was $5.0 \mathrm{~kW}$.

Figure 4 shows the pressure and enthalpy diagram, the cooling COP and the cooling capacity of the electrical air conditioning system using R744 for the fuel cell electric vehicle that was designed in this study. By using the refrigerant charge matching method for the air conditioning system as mentioned in Lee et al. [13], the refrigerant charge of the air conditioning system for cooling was set at $2.0 \mathrm{~kg}$ for the evaporator air temperature of $35.0^{\circ} \mathrm{C}$, air flow rate of $7.0 \mathrm{~m}^{3} / \mathrm{min}$, and relative humidity of $50 \%$. The same setting was used for the air temperature of $35^{\circ} \mathrm{C}$ and air velocity of $2.0 \mathrm{~m} / \mathrm{s}$ in the gas cooler.

In addition, the mass flow rate of the air conditioning system for acceptable cooling was $145.0 \mathrm{~kg} / \mathrm{h}$ at the frequency of $60.0 \mathrm{~Hz}$ and compressor speed of $4000 \mathrm{rev} / \mathrm{min}$. Figure $4 \mathrm{a}$ shows the pressure and enthalpy diagram according to the gas cooler inlet pressure. The tested system is operated in the transcritical region. This cycle has two different characteristics compared with the conventional system of the internal combustion engine. Firstly, It shows that the expansion device used in this study automatically and effectively controlled the system using the pulse width modulation (PWM) technique instead of a thermostatic expansion valve (TXV) [14,15]. Namely, it controlled the amount of pressure drop according to cooling load, and it properly impacted the compressor work. Secondly, the electric compressor for R744 driven by inverter is installed instead of the conventional belt driven compressor coupled to the engine. It is 
actively controlled to adjust cooling loads in the system as varying the refrigerant flow rate. The superheat temperatures over $12{ }^{\circ} \mathrm{C}$ between the evaporator outlet and the compressor inlet are designed for a stable cycle operation and a steady state performance.

In Figure 4b, the cooling COP and the cooling capacity for the evaporator were tested according to the variations of the inlet air conditions of the gas cooler. The cooling COP and the cooling capacity increased by $30.3 \%$ up to 2.5 and $36.8 \%$ up to $6.4 \mathrm{~kW}$, respectively, with the rise of the gas cooler inlet pressure from 92.0 bar to 102.0 bar at the gas cooler inlet temperature of $35.0^{\circ} \mathrm{C}$ and the compressor speed of $4000 \mathrm{rev} / \mathrm{min}$. In addition, the cooling capacity increased with rise of the compressor speed but the cooling COP reduced. This is because the compressor work quite increased due to the increasing compression ratio and specific volume at the compressor inlet. This is consistent with the result of Kim et al. [16].

Figure 4. Effects of the compressor speed on cooling performance of the air conditioning system according to gas cooler inlet pressure. (a) Pressure and enthalpy diagram; (b) Cooling capacity and cooling COP; (c) Compressor work and outlet air temperature of the gas cooler.

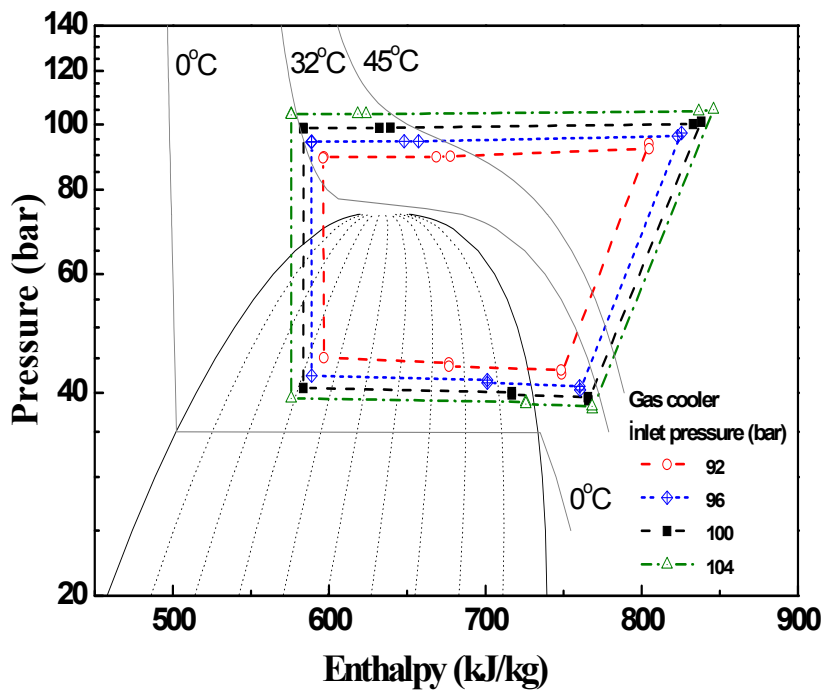

(a)

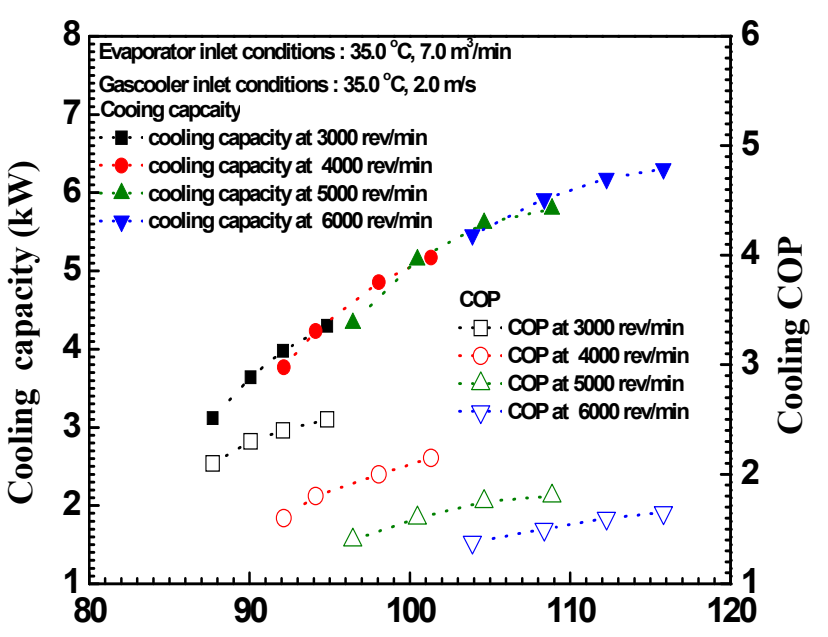

Gas cooler inlet pressure (bar)

(b)

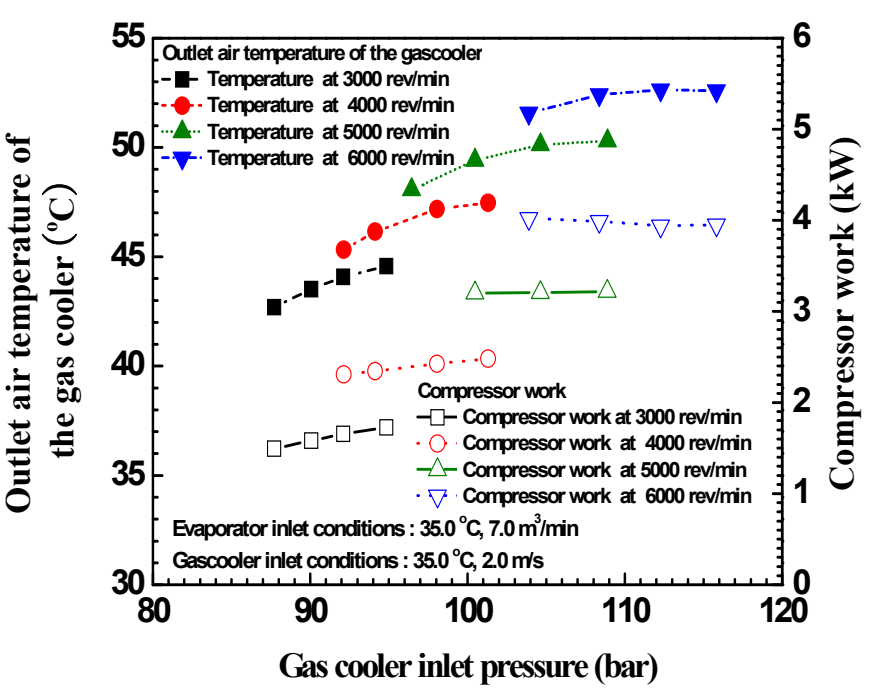

(c) 
The air outlet temperature of the gas cooler increased with rise of the compressor speed because of the increased refrigerant temperature of the gas cooler due to the increased operation pressure in the air conditioning system with the rise of the gas cooler inlet pressure, as shown in pressure and enthalpy diagram of Figure $4 \mathrm{a}$. The air outlet temperature of the gas cooler is an important parameter because it is the inlet temperature of the stack radiator for a fuel cell electric vehicle. Generally, the air outlet temperature of the gas cooler in a fuel cell electric vehicle is restricted under $60{ }^{\circ} \mathrm{C}$ to prevent the decrease of the cooling efficiency in the stack radiator. This mutual influence on heat exchanger arrangement (condenser or gas cooler and radiators) of the fuel cell electric vehicle is a crucial design point of the thermal management system and cooling system as mentioned in Lee et al. [17].

Figure 5 shows the cooling COP and cooling capacity of the electrical air conditioning system with the variations of the inlet air conditions of the gas cooler. The cooling COP and the cooling capacity were decreased with the increase of the inlet air temperature of the gas cooler. At the gas cooler inlet pressure of 90.0 bar, the cooling COP and the cooling capacity decreased by $55.6 \%$ and $55.1 \%$, respectively, with the rise of the gas cooler air inlet temperature from $27{ }^{\circ} \mathrm{C}$ to $42{ }^{\circ} \mathrm{C}$ due to the decreased heat transfer efficiency of the gas cooler, so the increase of the inlet air temperature of the gas cooler decreased the cooling capacity: the inlet air temperature of the gas cooler increased, and a temperature difference was produced between the air and the refrigerant of the gas cooler at the compressor speed of $4000 \mathrm{rev} / \mathrm{min}$, as shown in Figure 5a. As a result, the inlet air temperature variations of the gas cooler have a strong impact on the cooling capacity and cooling COP of the tested system. Figure $5 \mathrm{~b}$ shows effects of the inlet air velocity of the gas cooler on the COP and cooling capacity according to the gas cooler inlet pressure. The cooling capacity was increased with the increase of the gas cooler inlet air velocities from $2.0 \mathrm{~m} / \mathrm{s}$ to $4.0 \mathrm{~m} / \mathrm{s}$ due to the increased heat transfer efficiency from the gas cooler to the ambient. And the cooling COP also increased with the reduced compressor work because the specific refrigerating effect increased with increasing inlet air velocity. In addition, the variation of the gas cooler inlet air temperature had more effect on the cooling COP and cooling capacity of the tested system than the variation of gas cooler inlet air velocity did.

Figure 5. Effects of the inlet air conditions of the gas cooler on the cooling COP and cooling capacity according to gas cooler inlet pressure. (a) Gas cooler inlet air temperature;

(b) Gas cooler inlet air velocity.

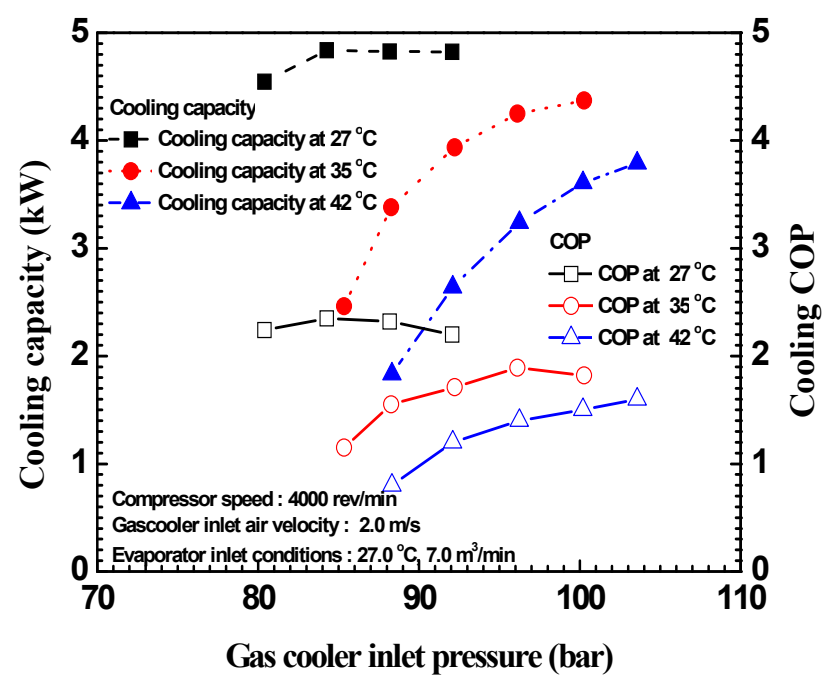

(a)

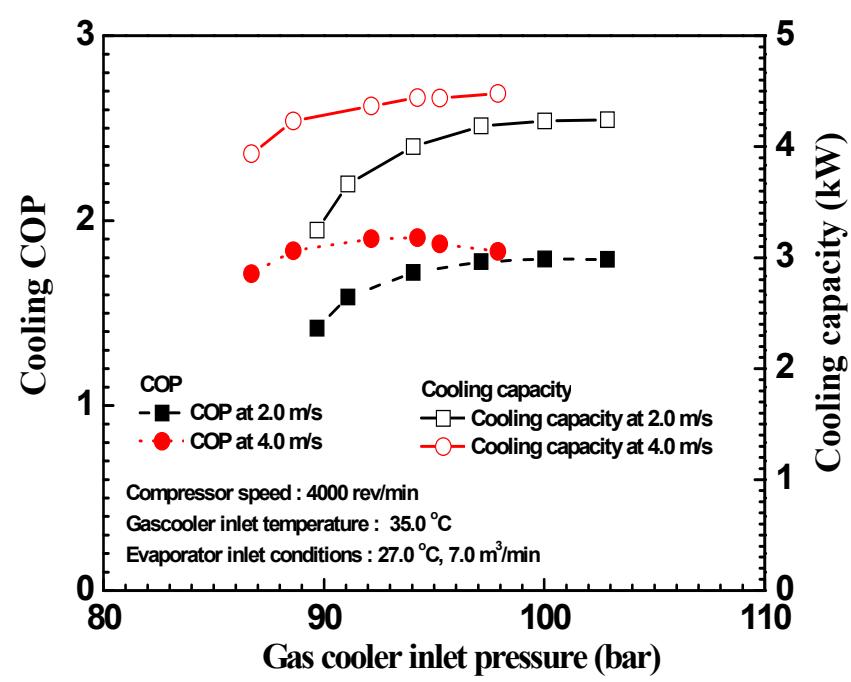

(b) 
Figure 6 shows the cooling COP and cooling capacity of the electrical air conditioning system with the variations of the inlet air conditions of the evaporator. The cooling COP and the cooling capacity averagely increased slightly with the rise of the evaporator inlet air temperatures from $27.0{ }^{\circ} \mathrm{C}$ to $35.0^{\circ} \mathrm{C}$. This is because the cooling capacity increased to match the cooling loads for the cabin and the specific refrigerating effect in the evaporator is also increased. However, at the gas cooler inlet pressure of 92.0 bar, the cooling COP and the cooling capacity decreased slightly with rise of the evaporator inlet air temperatures from $27.0^{\circ} \mathrm{C}$ to $35.0^{\circ} \mathrm{C}$. In addition, the increased amount of cooling capacity was greater than that of the cooling COP because the compressor works increased due to the increased refrigerant mass flow rate. Figure $6 \mathrm{~b}$ shows effects of the inlet air flow rate of the evaporator on the cooling COP and cooling capacity according to gas cooler inlet pressure. The cooling COP and the cooling capacity were increased with the rise of the evaporator inlet air flow rate from $4.0 \mathrm{~m}^{3} / \mathrm{min}$ to $7.0 \mathrm{~m}^{3} / \mathrm{min}$ due to the increased heat transfer efficiency of the evaporator. Therefore, the variation of the evaporator inlet air flow rate had a slightly more effect on the cooling capacity and cooling COP of the tested system than the variation of the evaporator inlet air temperature did.

Figure 6. Effects of the inlet air conditions of the evaporator on the cooling COP and cooling capacity according to gas cooler inlet pressure. (a) Evaporator inlet air temperature; (b) Evaporator inlet air velocity.

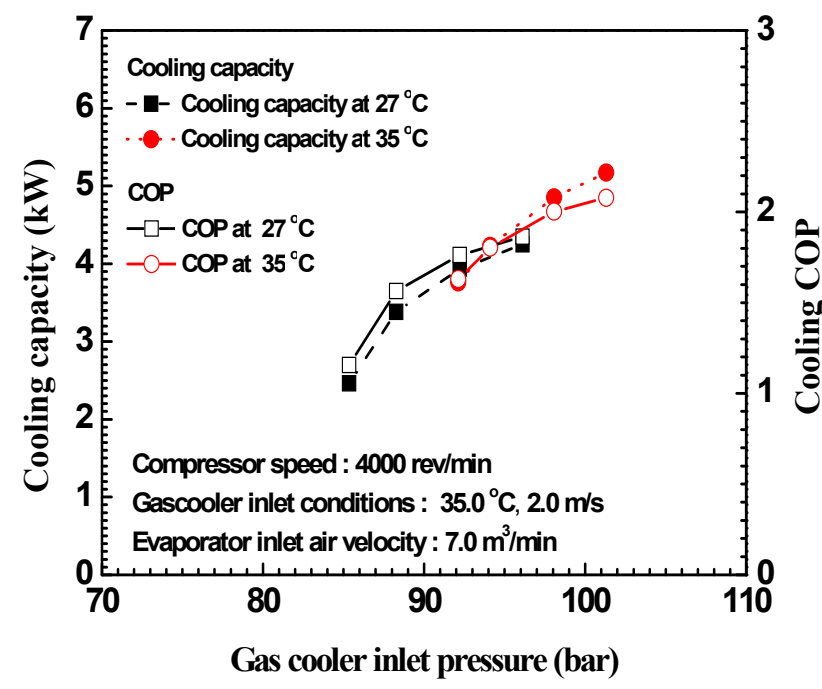

(a)

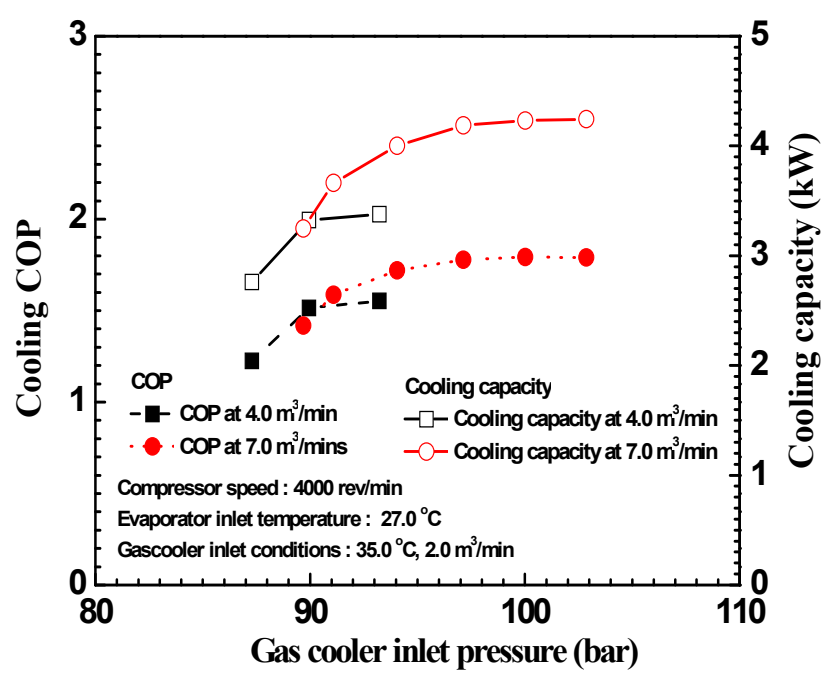

(b)

Figure 7 shows comparison of performances of the electrical air conditioning system using R744 and the conventional air conditioning system using R-134a. 
Figure 7. Performance comparison of the electrical air conditioning system using R744 with the conventional air conditioning system using R-134a.

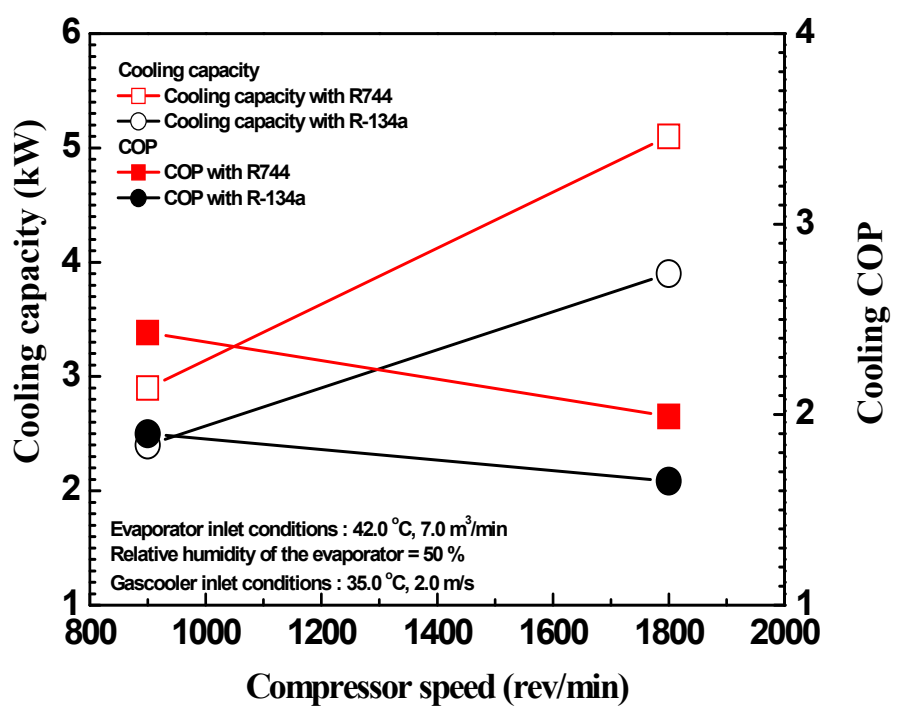

Two air conditioning systems were tested and compared under evaporator inlet air temperature of $42{ }^{\circ} \mathrm{C}$, relative humidity of $50 \%$, air flow rate of $7.0 \mathrm{~m}^{3} / \mathrm{min}$, gas cooler for R744 (and condenser for $\mathrm{R}-134 \mathrm{a}$ ) inlet temperature of $35^{\circ} \mathrm{C}$ and gas cooler for R744 (and condenser for R-134a) inlet air velocity of $2.0 \mathrm{~m} / \mathrm{s}$. And the electric compressor speeds for R744 and the belt driven compressor speeds for R-134a under the given conditions were selected to $900 \mathrm{rev} / \mathrm{min}$ and $1800 \mathrm{rev} / \mathrm{min}$. The cooling performances of the electrical air conditioning system using an inverter driven compressor for R744 was higher than that of the conventional air conditioning system with R-134a. The cooling COP of the electrical air conditioning system using R744 was on average $24.3 \%$ higher than that using $\mathrm{R}-134 \mathrm{a}$ at all compressor speeds. Therefore, the developed air conditioning system using R744 considered for a cabin cooling of the fuel cell electric vehicle showed better cooling performance than the conventional air conditioning system using R-134a. That is, the developed air conditioning system could be very helpful for improving the driving efficiency of the fuel cell electric vehicle because it would consume less electric energy from the stack and provide higher cooling COP. However, the cooling COP of both air conditioning systems was decreased with the increase of the compressor speed from $900 \mathrm{rev} / \mathrm{min}$ to $1800 \mathrm{rev} / \mathrm{min}$ because the compressor work increased noticeably. This is consistent with the results of Yang et al. and Lee et al. [18,19].

\section{Conclusions}

This study investigated the cooling performance characteristics of the electrical air conditioning system using R744 for a fuel cell electric vehicle. In this investigation, the inlet air conditions of both gas cooler and evaporator and the compressor speed were varied. Experimental results showed that the cooling capacity and cooling COP of the electrical air conditioning system using R744 were sufficient to cover the cooling load of the fuel cell electric vehicle under hot weather conditions and the cooling capacity and the cooling COP of the tested system increased up to $6.4 \mathrm{~kW}$ and 2.5 , respectively. As a result, the developed electrical air conditioning system could be very helpful for improving the driving efficiency of the fuel cell electric vehicle because it would consume less electric energy from the high 
voltage battery system and provide higher cooling COP. In addition, the electrical air conditioning system with R744 using an inverter driven compressor showed better performance than the conventional air conditioning system with R-134a under the same operating conditions.

(1) The cooling COP and the cooling capacity increased by $30.3 \%$ up to 2.5 and $36.8 \%$ up to $6.4 \mathrm{~kW}$, respectively, with the rise of the gas cooler inlet pressure from 92.0 bar to 102.0 bar at the gas cooler inlet temperature of $35.0^{\circ} \mathrm{C}$ and the compressor speed of $4000 \mathrm{rev} / \mathrm{min}$.

(2) The cooling capacity increased with rise of the compressor speed but the cooling COP was reduced because the compressor work increased due to the increased compression ratio and specific volume at the compressor inlet.

(3) At the gas cooler inlet pressure of 90.0 bar, the cooling COP and the cooling capacity decreased by $55.6 \%$ and $55.1 \%$, respectively, with the rise of the gas cooler air inlet temperature from $27{ }^{\circ} \mathrm{C}$ to $42{ }^{\circ} \mathrm{C}$ due to the decreased heat transfer efficiency of the gas cooler.

(4) Under extremely hot weather conditions over $35.0^{\circ} \mathrm{C}$, the cooling capacity of the tested system was sufficient, over $5.0 \mathrm{~kW}$, at the compressor speed over $4500 \mathrm{rev} / \mathrm{min}$.

(5) The cooling COP of the electrical air conditioning system using R744 was on average $24.3 \%$ higher than that using R-134a at all compressor speeds.

\section{Acknowledgments}

This work was supported by the grant "Development of carbon dioxide mobile A/C system (10005246)" from the Korea Institute of Energy Technology Evaluation and Planning.

\section{References}

1. Halozan, H.; Rieberer, R. $\mathrm{CO}_{2}$ as refrigerant-possible application. In Proceedings of the 4th IIR-Gustav Lorentzen Conference on Natural Working Fluids at Purdue, West Lafayette, IN, USA, 2000; pp. 455-462.

2. Rozhentsev, A.; Wang, C. Some design features of a $\mathrm{CO}_{2}$ air conditioner. Appl. Therm. Eng. 2001, 21, 871-880.

3. Cho, C.W.; Lee, H.S.; Won, J.P.; Lee, M.Y. Measurement and evaluation of heating performance of heat pump systems using wasted heat from electric devices for an electric bus. Energies 2012, 5, 658-669.

4. Lorentzen, G.; Pettersen, J. A new efficient and environmentally benign system for car air-conditioning. Int. J. Refrig. 1993, 16, 4-12.

5. Brown, J.S.; Yana-Motta, S.F.; Domanski, P.A. Comparative analysis of an automotive air conditioning systems operating with $\mathrm{CO}_{2}$ and R134a. Int. J. Refrig. 2002, 25, 19-32.

6. Park, M.; Kim, S.C.; Kim, D.W.; Kim, M.S. Studies on the steady state and dynamic characteristics of a carbon dioxide air-conditioning system for vehicles. Trans. KSME 2007, 31, 531-538.

7. Tamura, T.; Yakumaru, Y.; Nishiwaki, F. Experimental study on automotive cooling and heating air conditioning system using $\mathrm{CO}_{2}$ as a refrigerant. Int. J. Refrig. 2005, 25, 1302-1307. 
8. Kim, S.C.; Won, J.P.; Kim, M.S. Effects of operating parameters on the performance of a $\mathrm{CO}_{2}$ air conditioning system for vehicles. Appl. Therm. Eng. 2009, 29, 2408-2416.

9. Kim, S.C.; Won, J.P.; Park, Y.S.; Lim, T.W.; Kim, M.S. Performance evaluation of a stack cooling system using $\mathrm{CO}_{2}$ air conditioning system in fuel cell vehicles. Int. J. Refrig. 2009, 32, 70-77.

10. ANSI/AMCA 210. Laboratory Methods of Testing Fans for Rating; American National Standards Institute (ANSI): Arlington, VA, USA, 1985.

11. Moffat, R.J. Uncertainty analysis in the planning of an experiment. J. Fluid. Eng. 1985, 107, $173-178$.

12. ASHRAE Standard 116. Methods of Testing for Seasonal Efficiency of Unitary Air-Conditioners and Heat Pumps: Amer Society of Heating: Atlanta, GA, USA, January 1983.

13. Lee, M.Y.; Cho, C.W.; Lee, H.S.; Won, J.P. Performance characteristics of the electrical air conditioning system for the zero emission passenger vehicle. Trans. KAIS 2012, 12, 5430-5437.

14. Yin, J.; Park, Y.C.; Boewe, D.; Mc-Enaney, R.; Beaver, A.; Bullard, C.W.; Hrnjak, P.S. Experimental and model comparison of transcritical $\mathrm{CO}_{2}$ versus $\mathrm{R} 134 \mathrm{a}$ and $\mathrm{R} 410$ system performance. In Proceedings of the Third IIR-Gustav Lorentzen Conference on Natural Working Fluids, Oslo, Norway, 1998; pp. 331-340.

15. He, Z.; Jing, Lv.; Yang, D.; Huang, X. Research of the $\mathrm{CO}_{2}$ heat pump system for automotive air conditioning. In Proceeding of the International Conference on Energy and Environment Technology, Guilin, China, 16-18 October 2009; pp. 275-278.

16. Kim, S.C.; Kim, M.S.; Hwang, I.C.; Lim, T.W. Performance evaluation of a $\mathrm{CO}_{2}$ heat pump system for fuel cell vehicles considering the heat exchanger arrangements. Int. J. Refrig. 2007, 30, 1195-1206.

17. Lee, M.Y.; Won, J.P.; Cho, C.W.; Lee, H.S. Experimental study on the mutual influence of thermal management system for hydrogen fuel cell vehicle. Trans. Korean Hydrog. New Energy Soc. 2011, 22, 852-858.

18. Yang, W.W.; Fartaj, A.; Ting, D.S. $\mathrm{CO}_{2}$ automotive A/C system optimum high pressure control. SAE Int. 2005, doi: 10.4271/2005-01-2022.

19. Lee, H.S.; Cho, C.W.; Won, J.P.; Lee, M.Y. Study on cooling performance characteristics of air conditioning system using R744 for a passenger vehicle. J. Korea Acad. Ind. Coop. Soc. 2011, 12, $5457-5463$.

(C) 2012 by the authors; licensee MDPI, Basel, Switzerland. This article is an open access article distributed under the terms and conditions of the Creative Commons Attribution license (http://creativecommons.org/licenses/by/3.0/). 